\title{
Efektivitas Ekstrak Daun Kejibeling Untuk Meningkatkan Fagositosis Makrofag dan Produksi Roi Makrofag "Studi Eksperimental pada mencit Swiss yang Diinfeksi Staphylococcus aureus"
}

\author{
Annaas Budi Setyawan \\ Stikes Muhammadiyah Samarinda Jalan Ir. H. Juanda No. 15 Samarinda \\ Email: sutini.mgt@gmail.com
}

\begin{abstract}
ABSTRAK
Penelitian ini membuktikan ekstrak daun kejibeling terhadap peningkatan fagositosis dan produksi ROI makrofag pada mencit yang diinfeksi bakteri S.aureus. Mencit dibagi menjadi empat kelompok. Kelompok kontrol (K), mencit diinfeksi bakteri S.aureus. Kelompok perlakuan (P1, P2, P3), mencit diinfeksi bakteri S.aureus diberi ekstrak daun kejibeling dengan dosis bertingkat $150 ; 300 ; 600 \mathrm{mg} / \mathrm{kgBB}$. Pemberian ekstrak daun kejibeling dilakukan selama delapan hari diinjeksi bakteri S.aureus $10^{8}$ cfu sebanyak 0,2 $\mathrm{mL}$ dilakukan hari pertama secara intraperitoneal. Fagositosis makrofag dilakukan uji Annova dilanjutkan uji LDS. Produksi ROI makrofag dilakukan uji Kruskal wallis dilanjutkan uji Mann whitney $U$. Kedua uji hipotesis didapatkan $p<0,05$. Fagositosis makrofag uji LSD terdapat perbedaan bermakna kelompok kontrol(K) dengan perlakuan (P1,P2,P3) sedangkan kelompok perlakuan didapatkan perbedaan tidak bermakna yaitu; $\mathrm{P} 1$ dengan $\mathrm{P} 3(p=0,150)$ dan $\mathrm{P} 2$ dengan $\mathrm{P} 3(p=0,646)$. Produksi ROI makrofag pada uji Post Hoc dengan Mann Whitney menunjukkan perbedaan bermakna antar kelompok dengan nilai $p<0,05$. Ekstrak daun kejibeling dosis $150 \mathrm{mg} / \mathrm{kgBB}$ bermakna meningkatkan fagositosis makrofag dan produksi ROI.
\end{abstract}

Kata kunci: Daun kejibeling, Fagositosis, ROI makrofag

\begin{abstract}
The aim of this experiment is to study the effect of Strobillanthes crispus on phagocytosis and ROI of macrophage in mice peritoneum which infected with S.aureus. The research used a post test only control group design consist of 24 male swiss mice which randomly signed into four group,control group $(K)$ was infected by S.aureus but not given an extracts. Treatment group (P1,P2,P3) were infected by S.aureus $10^{8} \mathrm{cfu} / \mathrm{mL}$ and fed with S.crispus extracts at different dosages $(150 ; 300 ; 600 \mathrm{mg} / \mathrm{kgbw})$. To analyzed the machropage phagocytosis activity by Anova and Kruskal wallis. The machropage phagocytosis activity on the Post Hoc using LSD test resulted in significant difference control group $(\mathrm{K})$ and treatments $(\mathrm{P} 1, \mathrm{P} 2, \mathrm{P} 3)$. This research also found an insignificant difference between $\mathrm{P} 1$ and $\mathrm{P} 3$ (p:0.150);P2 and P3(p:0.646). ROI production on Post Hoc test using mann whitney resulted in a significant difference between groups (p:0.05). The $150 \mathrm{mg} / \mathrm{kgbw}$ S.crispus extract were capable of enhancing machropage phagocytosis and ROI production in a significant manner.
\end{abstract}

Keywords: Strobillanthes crispus, Phagocytosis, ROI Machrophage 


\section{Pendahuluan}

Infeksi nosokomial sering terjadi di rawat inap. Bahkan negara besar seperti Amerika mengeluarkan dana sebesar \$4,1 miliar - \$11 miliar untuk mengatasi dua juta pasien/tahun yang terserang infeksi nosokomial (Klein, et al, 2007). Banyaknya bakteri yang ditemukan resisten terhadap antibiotik di anggap sebagai penyebab infeksi nosokomial dan salah satu bakteri yang teridentifikasi sering menyebabkan infeksi nosokomial yaitu Staphylococcus aureus sebesar 21,7\%. Saat ini diketahui sekitar $40 \%$ bakteri S.aureus yang dapat diisolasi di rumah sakit resisten terhadap beberapa jenis antibiotik turunan $\beta$-laktam dan sefalosporin, tetapi masih sensitif terhadap antibiotik vankomisin dan klindamisin (Sulistiyaningsih, 2010).

Staphylococcus adalah bakteri intraseluler, sehingga sistem imun seluler berperan penting dalam pertahanan tubuh terhadap penyakit ini. Fagosit baik mononuklear maupun polimorfonuklear berperan dalam menghambat replikasi bakteri. Sel-sel imunokompeten dapat membunuh mikroba dengan dua cara yaitu fagositosis bakteri intraseluler oleh makrofag dan lisis sel yang terinfeksi oleh limfosit T dan sel NK (Christian, et al, 2008). Dalam proses fagositosis terdapat tiga fase yaitu fase pengenalan, degranulasi, dan pembunuhan atau killing. ROI (Reactive Oxygen Intermediate) terdiri atas radikal peroksida, radikal hidroksil dan singlet oksigen, ROI sangat reactive dalam proses membunuh bakteri. prosesnya sendiri terjadi beberapa saat setelah fagositosis dan dikenal sebagai respiratory burst (percepatan respirasi) yang terjadi karena stimulasi jalur metabolic (Baratawidjaja, 2009).

Respiratory burst dimulai dengan adanya perubahan $\mathrm{O}_{2}$ menjadi

Jurnal Sains dan Kesehatan. 2015. Vol 1. No 4. p-ISSN: 2303-0267, e-ISSN: 2407-6082
$\mathrm{O}_{2}^{-}$dengan bantuan enzim NADPH oksidase, kemudian dalam reaksi yang dikatalisis oleh Superoksida Dismutase (SOD), dua molekul yaitu masingmasing $\mathrm{H}^{+}$dan $\mathrm{O}^{-}$dan membentuk $\mathrm{H}_{2} \mathrm{O}_{2}$, sedangkan di netrofil $\mathrm{H}_{2} \mathrm{O}_{2}$ tersebut akan dikonversi membentuk molekul bakterisidal oleh enzim Mieloperoksidase (MPO). Dengan adanya $\mathrm{Fe}^{2+}$ maka $\mathrm{O}_{2}^{-}$dan $\mathrm{H}_{2} \mathrm{O}_{2}$ akan bereaksi membentuk $\mathrm{OH}$ dan $\mathrm{O}_{2}$ (singlet oksigen) yang sangat reaktif sebagai bakterisid. Dikatakan bahwa molekul-molekul diatas khususnya $\mathrm{H}_{2} \mathrm{O}_{2}$ berperan sangat penting dalam bacterial killing oleh makrofag terhadap S.aureus karena bersifat bakterisid (Baratawudjaja, 2009).

Pengetahuan tentang khasiat dan keamanan tanaman obat di Indonesia biasanya hanya berdasarkan pengalaman empiris yang biasanya diwariskan secara turun temurun dan belum teruji secara ilmiah. Untuk itu diperlukan penelitian tentang obat tradisional, sehingga nantinya obat tersebut dapat digunakan dengan aman dan efektif. Sekitar $80 \%$ individu dari negara berkembang menggunakan pengobatan tradisional dengan bahan yang berasal dari tanaman obat. Penggunaan ekstrak dan zat fitokimia tanaman yang memiliki kandungan antimikroba dapat menjadi dasar penemuan antibiotik baru dalam terapi kasus infeksi bakteri (Nugrahani, 2012).

Ekstrak daun kejibeling memiliki aktivitas yang tinggi sebagai antibakteri, secara invitro terbukti terhadap bakteri S.aureus dan Bacillus cereus (Muskhazli, et al, 2009). Aktivitas antibakteri yang tinggi dari ekstrak daun $S$. crispus karena adanya beberapa senyawa kimia dalam ekstrak daun ini, seperti polifenol, catechin, kafein, alkaloid, tanin, $\beta$-sitosterol dan stigmaste. Penelitian lain mengenai uji toksiksitas daun kejibeling sudah pernah diteliti dengan menunjukkan pertumbuhan normal dan sehat tanpa 
tanda-tanda toksisitas pada hewan coba (Nurraihana, et al, 2010). Penelitian ini bertujuan untuk membuktikan efek ekstrak daun kejibeling terhadap peningkatan aktifitas fagositosis makrofag dan produksi ROI makrofag pada mencit putih Strain Swiss yang di infeksi bakteri S.aureu sehingga diharapkan dapat menjadi landasan untuk bekal penelitian lebih lanjut pada manusia.

\section{Metode}

Tiga puluh mencit putih galur swiss (Jenis kelamin jantan, umur 8-10 minggu, berat badan 20-30 gram) dibagi secara acak dalam empat kelompok masing-masing 6 ekor. Kelompok kontrol (K), hanya diberi pakan dan minum standar. Kelompok perlakuan (P1,P2,P3), mencit diinfeksi bakteri S.aureus kemudian diberi ekstrak daun kejibeling dengan dosis bertingkat 150;300;600 mg/kg BB. Dosis berdasar penelitian sebelumnya yang digunakan untuk mengukur toksisitas ekstrak daun kejibeling. ${ }^{10}$ Pemberian ekstrak daun kejibeling dilakukan selama delapan hari dan injeksi bakteri S.aureus dilakukan pada hari pertama dengan konsentrasi $10^{8} \mathrm{cfu}$ sebanyak $0,2 \mathrm{~mL}$ intraperitoneal.

Pada hari terakhir perlakuan mencit dieuthanasia dengan overdosis ether. Setelah itu mencit diletakan dalam posisi telentang pada gabus yang telah dilapisi alumunium foil, kemudian kulit bagian perut didesinfeksi dengan alkohol $70 \%$. Selanjutnya kulit bagian perut dibuka dengan gunting steril sehingga tampak lapisan cavum peritoneum beserta isinya. Selanjutnya disuntikan $\pm 10 \mathrm{ml}$ RPMI dingin ke rongga peritoneum. Selanjutnya didiamkan selama \pm 3 menit sambil digoyang-goyang secara perlahan. Cairan peritoneal dikeluarkan dan diaspirasi dengan jarum suntik. Jarum yang berisi bahan aspirasi diletakkan

Jurnal Sains dan Kesehatan. 2015. Vol 1. No 4. p-ISSN: 2303-0267, e-ISSN: 2407-6082 dalam gelas beker berisi es, kemudian aspirat disentrifugasi pada $1200 \mathrm{rpm} 40^{\circ}$ C selama 10 menit. Supernatan yang terbentuk dibuang dan kemudian ditambahkan $3 \mathrm{ml}$ medium RPMI komplit (mengandung FCS 10\%). Jumlah sel makrofag dihitung dengan hemositometer kemudian diresuspensikan dengan medium komplit sehingga didapatkan suspensi sel dengan kepadatan $2,5 \times 10^{6 /} \mathrm{ml}$. Suspensi sel yang telah dihitung dikulturkan dalam plate 24 sumuran yang telah diberi coverslip bulat, setiap sumuran berisi $200 \mu \mathrm{l}\left(5 \times 10^{5} \mathrm{sel}\right)$. Sel diinkubasikan dalam inkubator $\mathrm{CO}_{2}$ $5 \%, 37^{\circ} \mathrm{C}$ selama 30 menit (Tjahajati, 2005).

Kemampuan fagositosis non spesifik dilakukan in vitro menurut Leijh dkk. (1986) dengan menggunakan latex beads. Latex beads diresuspensikan sehingga mendapat konsentrasi 2,5 x $10^{7} / \mathrm{ml}$. Makrofag yang telah dikultur sehari sebelumnya dicuci dengan RPMI 2 kali, kemudian ditambahkan suspensi lateks $200 \mu \mathrm{l} /$ sumuran dan diinkubasikan selama 60 menit pada $37^{\circ} \mathrm{C}, \mathrm{CO}_{2} 5 \%$. Sel dicuci $3 x$ dengan PBS (untuk menghilangkan partikel yang tidak difagositosis). Aktivitas fagositosis makrofag dinilai dari persentase makrofag yang memfagositosis partikel latex, dihitung dari 100 makrofag yang terlihat di bawah mikroskop cahaya, dan rerata jumlah partikel latex yang difagositosis oleh setiap makrofag. Rerata jumlah partikel latex yang difagositosis oleh setiap makrofag dihitung dengan cara membagi jumlah partikel latex yang difagositosis dengan jumlah makrofag yang memfagositosis partikel latex (Tjahajati, 2005).

Suspensi makrofag yang telah dihitung dan dikultur pada microplate 12 well yang telah diberi coverslip bulat, setiap sumuran $200 \mu \mathrm{L}\left(5 \times 10^{5}\right.$ sel), diinkubasikan dalam inkubator $\mathrm{CO}_{2} 5 \%, 37^{\circ} \mathrm{C}$ selama 60 menit. 
Memasukan $500 \mu \mathrm{l}$ larutan NBT yang mengandung $125 \mathrm{ng} / \mathrm{ml}$ PMA. Pada sumuran kontrol hanya diberi NBT saja, diinkubasi dalam inkubator $\mathrm{CO}_{2} \quad 5 \%$ pada suhu $37^{\circ} \mathrm{C}$ selama 60 menit. Sel dicuci dengan PBS 3x lalu dikeringkan pada suhu kamar. Sel dicuci dengan PBS 3x lalu dikeringkan pada suhu kamar, fiksasi dengan methanol absolut selama 2 - 3 menit. Aktivitas makrofag untuk memproduksi ROI diukur dengan menghitung persentase makrofag yang mensekresi ROI yaitu yang menunjukkan pembentukan formazan (warna gelap), dihitung 100 makrofag yang terlihat dibawah mikroskop cahaya, dan skor derajat pembentukan formazan oleh tiap 100 makrofag, dihitung dengan cara menjumlahkan besarnya skor yang dicapai oleh 100 makrofag. Skor 0 jika pada makrofag tidak terbentuk formazan, skor 1 jika pada makrofag terbentuk formazan tetapi tidak memenuhi seluruh sel, dan skor 2 jika formazan yang terbentuk memenuhi seluruh sel (Tjahajati, 2005). Penilaian aktifitas fagositosis makrofag dilakukan uji hipotesis Annova dilanjutkan analisis Post Hoc dengan uji LDS. Dan penilaian produksi ROI makrofag dilakukan uji hipotesis Kruskal wallis dilanjutkan analisis Post Hoc dengan uji Mann whitney $U$.

\section{Hasil dan Pembahasan}

Aktivitas fagositosis yang dinilai dari persentase makrofag yang memfagositosis latex, menunjukkan bahwa persentase fagositosis kelompok perlakuan yang diberi ekstrak daun kejibeling lebih tinggi dibandingkan dengan kelompok kontrol. Hal yang serupa nampaknya juga terlihat pada pola hasil penghitungan rata-rata latex yang difagositosis oleh setiap makrofag. Tabel.1 didapatkan bahwa data yang diujikan berdistribusi normal $(p>0,05)$, selanjutnya dilakukan uji beda statistik parametrik Annova didapatkan perbedaan yang bermakna antar kelima kelompok $(p=0,001)$ Selanjutnya dilakukan uji statistik Post Hoc LDS untuk mengetahui perbedaan masingmasing kelompok, hasil dapat dilihat pada tabel 2.

Hasil mean persentase makrofag yang memfagositosis latex pada penelitian tertinggi pada kelompok perlakuan P1 dan yang terendah pada kelompok $\mathrm{K}+$ dengan nilai uji Annova $p<0,05(p=0,001)$. Aktivitas fagositosis terendah didapat pada kelompok $\mathrm{K}+$ hal itu kemungkinan disebabkan penurunan respon imun adaptif karena proses imunitas adaptif pada umumnya bekerja 4-7 hari setelah terjadinya infeksi dan akan berangsur menurun pada hari berikutnya (Faroka, dkk, 2013). Pemberian ekstrak daun kejibeling pada kelompok P1 dengan dosis 150 $\mathrm{mg} / \mathrm{kgbb}$ menunjukkan peningkatan aktivitas fagositosis makrofag dengan perbedaan yang bermakna dibandingkan dengan kelompok lain. Hal ini disebabkan karena kandungan senyawa aktif dalam ekstrak daun kejibeling terutama tanin dan flavonoid. Hasil ini sejalan dengan penelitian mengenai ekstrak daun salam yang mengandung senyawa kimia flavonoid yang mampu meningkatkan fagositosis makrofag pada kelompok perlakuan. Hal ini memnunjukkan bahwa aktivitas pembunuhan terhadap bakteri juga meningkat (Lee dan Intan, 2012). Rata-rata latex yang difagositosis lebih tinggi pada kelompok mencit yang diberi ekstrak daun kejibeling dibanding dengan kelompok kontrol, dan puncak rata-rata tertinggi pada kelompok P1. Hasil uji normalitas didapatkan bahwa data berdistribusi normal $(p>0,05)$ kemudian dilanjutkan dengan uji Annova dengan nilai $p=0,001$ yang berarti ada perbedaan bermakna antar kelima kelompok (Tabel 1). Untuk mengetahui perbedaan masing-masing kelompok 
dilakukan uji statistik Post Hoc LDS (Tabel 2).

Penurunan aktivitas fagositosis makrofag dengan perbedaan yang tidak signifikan tampak pada kelompok P2 dan kelompok P3, Hal ini kemungkinan disebabkan oleh dua faktor. Faktor pertama, mungkin disebabkan oleh mekanisme ekstrak daun kejibeling sebagai imunomodulator yang akan meningkatkan respon imunitas hanya sampai batas tertentu yang apabila batas itu sudah tercapai maka penambahan dosis lebih lanjut tidak memberikan efek yang berarti. Faktor kedua, sistem imun memiliki mekanisme homeostasis yang menjaga agar tidak terjadi peningkatan respon imun yang berlebihan yang dapat menyerang jaringan tubuhnya sendiri (Lusiana, 2006).

Tabel 1. Persentase dan rerata makrofag

\begin{tabular}{|c|c|c|c|c|c|c|c|c|c|c|}
\hline \multirow[b]{2}{*}{ Kelompok } & \multirow[b]{2}{*}{$\mathrm{N}$} & \multicolumn{2}{|c|}{$\begin{array}{c}\text { Persentase } \\
\text { makrofag } \\
\text { memfagositosis } \\
\text { latex }\end{array}$} & \multicolumn{2}{|c|}{$\begin{array}{c}\text { Rerata latex yang } \\
\text { difagositosis } \\
\text { makrofag }\end{array}$} & \multicolumn{2}{|c|}{$\begin{array}{c}\text { Persentase } \\
\text { makrofag yang } \\
\text { mensekresi ROI }\end{array}$} & \multicolumn{2}{|c|}{$\begin{array}{c}\text { Rerata skor ROI } \\
\text { makrofag }\end{array}$} & \multirow[t]{2}{*}{$p$} \\
\hline & & Mean & $\begin{array}{l}\text { Min- } \\
\text { Max }\end{array}$ & Mean & $\begin{array}{l}\text { Min- } \\
\text { Max }\end{array}$ & Mean & $\begin{array}{l}\text { Min- } \\
\text { Max }\end{array}$ & Mean & Min-Max & \\
\hline $\mathrm{K}+$ & 6 & 40,00 & $36-44$ & 1,93 & $1,5-2,4$ & 36,33 & $29-40$ & 55,50 & $45-63$ & 0,001 \\
\hline $\mathrm{P} 1$ & 6 & 62,33 & $59-67$ & 5,23 & $4,6-5,8$ & 64,50 & $60-67$ & 99,33 & 94-105 & \\
\hline $\mathrm{P} 2$ & 6 & 60,50 & $55-65$ & 4,67 & $4,0-5,3$ & 57,33 & $52-62$ & 91,50 & $83-98$ & \\
\hline P3 & 6 & 59,67 & $56-63$ & 4,43 & $3,8-4,8$ & 56,17 & $51-60$ & 87,33 & $80-94$ & \\
\hline
\end{tabular}

Tabel 2. Perbedaan pada tiap kelompok

\begin{tabular}{|c|c|c|c|c|c|c|c|c|c|c|c|c|}
\hline & \multicolumn{3}{|c|}{$\begin{array}{c}\text { makrofag yang } \\
\text { memfagositosis latex }\end{array}$} & \multicolumn{3}{|c|}{$\begin{array}{c}\text { latex yang difagositosis } \\
\text { makrofag }\end{array}$} & \multicolumn{3}{|c|}{$\begin{array}{l}\text { Makrofag yang } \\
\text { mensekresi ROI }\end{array}$} & \multicolumn{3}{|c|}{$\begin{array}{l}\text { Rerata skor ROI } \\
\text { makrofag }\end{array}$} \\
\hline & $\mathrm{P} 1$ & $\mathrm{P} 2$ & P3 & $\mathrm{P} 1$ & $\mathrm{P} 2$ & $\mathrm{P} 3$ & $\mathrm{P} 1$ & $\mathrm{P} 2$ & $\mathrm{P} 3$ & $\mathrm{P} 1$ & $\mathrm{P} 2$ & P3 \\
\hline $\mathrm{K}+$ & $0,001^{\mathrm{a}}$ & $0,001^{\mathrm{b}}$ & $0,001^{\mathrm{c}}$ & $0,001^{\mathrm{a}}$ & $0,001^{\mathrm{b}}$ & $0,001^{\mathrm{c}}$ & $0,001^{\mathrm{a}}$ & $0,001^{\mathrm{b}}$ & $0,001^{\mathrm{c}}$ & $0,004^{\mathrm{a}}$ & $0,004^{\mathrm{b}}$ & $0,004^{\mathrm{c}}$ \\
\hline $\mathrm{P} 1$ & - & $0,317 *$ & $0,150 *$ & - & $0,015^{\mathrm{d}}$ & $0,001^{\mathrm{e}}$ & - & $0,002^{\mathrm{d}}$ & $0,001^{\mathrm{e}}$ & - & $0,045^{\mathrm{d}}$ & $0,005^{\mathrm{e}}$ \\
\hline $\mathrm{P} 2$ & - & - & $0,646^{*}$ & - & - & $0,294 *$ & - & - & $0,573 *$ & - & - & $0,170 *$ \\
\hline & $\begin{array}{l}\text { Terdapa } \\
\text { Terdapa } \\
\text { Terdapa }\end{array}$ & $\begin{array}{l}\text { perbeda } \\
\text { perbeda }\end{array}$ & $\begin{array}{l}\text { berma } \\
\text { berma }\end{array}$ & $\begin{array}{l}\mathrm{K}+\mathrm{d} \\
\mathrm{a} \mathrm{P} 1 \mathrm{~d}\end{array}$ & $\begin{array}{l}\text { ngan P3 } \\
\text { ngan P3 }\end{array}$ & & $\begin{array}{l}\text { erdapat } \\
\text { idak ter }\end{array}$ & $\begin{array}{l}\text { rbedaan } \\
\text { rbedaan } \\
\text { bat perb }\end{array}$ & $\begin{array}{l}\text { bermakn } \\
\text { bermakn } \\
\text { daan ber }\end{array}$ & $\begin{array}{l}\text { P1 den } \\
\text { lakna }\end{array}$ & $\begin{array}{l}\mathrm{P} 2 \\
\mathrm{P} 2\end{array}$ & \\
\hline
\end{tabular}

Hasil kemampuan produksi ROI makrofag dinilai dari persentase makrofag yang mensekresi ROI, menunjukkan bahwa persentase makrofag yang mensekresi ROI kelompok mencit yang diberi ekstrak daun kejibeling lebih tinggi dibandingkan dengan kelompok kontrol. Uji Shapiro- Wilk didapatkan distribusi data yang normal $(p>0,05)$. Uji beda menggunakan uji statistik parametrik Anova dengan nilai $p=0,001$ yang berarti ada perbedaan yang bermakna antara kelima kelompok tersebut (Tabel 1).

Dari hasil tersebut juga menunjukkan bahwa pemberian ekstrak daun kejibeling dapat meningkatkan produksi ROI makrofag dalam usahanya untuk memusnahkan S.aureus yang masuk kedalam tubuh mencit. Aktivitas fagositosis makrofag yang tinggi dapat diasumsikan bahwa makrofag yang mensekresi ROI juga akan tinggi (Tjahajati,2005). Peningkatan produksi ROI makrofag pada mencit 
swiss dikarenakan karena kandungan zat aktif tanin dan flavonoid yang berkhasiat sebagai antimikroba dan meningkatkan sistem imun tubuh dengan menstimulasi sel-sel fagosit yang berperan dalam respon imun seluler. Hasil ini sejalan dengan penelitian mengenai teh hijau yang mengandung senyawa kimia tanin yang mampu meningkatkan produksi ROI makrofag (Taylerson, 2012). Dengan adanya senyawa zat aktif tersebut memungkinkan terjadi peningkatan produksi IL-12 yang akan menstimulasi sel NK, membantu deferensiasi Th menjadi Th1. Sel ini akan mensekresi IFN- $\gamma$ yang berfungsi mengaktivasi makrofag untuk memproduksi oksigen reaktif yaitu ROI (Reaktive oxygen intermediate) (Baratawidjaja, 2009).

Skor ROI yang disekresi oleh makrofag (formazan yang terbentuk) diperoleh lebih tinggi pada kelompok mencit yang diberi ekstrak daun kejibeling dibanding dengan kelompok kontrol, dengan puncak tertinggi skor ROI pada kelompok P1. Diuji normalitasnya dengan uji normalitas Shapiro- Wilk distribusi data tidak normal $(p<0,05)$. Selanjutnya dilakukan uji beda menggunakan uji statistik parametrik kruskal wallis. Pada tabel 1 didapatkan perbedaan yang bermakna antara kelima kelompok tersebut dengan nilai $p=0,001 \quad(p<0,05)$. Perbedaan masing-masing kelompok dilanjutkan dengan uji statistik Mann Whitney (Tabel 2)

Ada penurunan produksi ROI yaitu pada kelompok perlakuan $\mathrm{P} 2$ dan P3. Hal ini mungkin terjadi karena adanya mekanisme penghambatan dari NO dan pelindung dari katalase dan glutation peroksidase untuk melindungi diri dari kerusakan oksidatif akibat produksi ROI. ROI merupakan komponen sangat reaktif dalam membunuh dan menghancurkan bakteri, apabila ROI diproduksi secara terus menerus akan mengakibatkan kerusakan Jurnal Sains dan Kesehatan. 2015. Vol 1. No 4. p-ISSN: 2303-0267, e-ISSN: 2407-6082 jaringan tubuh yang lain, dengan kemungkinan adanya peningkatan NO akan menghambat efek sitotoksik dari ROI (Nathan, 2000). Hal ini yang menjadi penyebab terjadi penurunan produksi ROI pada kelompok perlakuan seperti pada penelitian ini.

\section{Penutup}

Dari hasil dan diskusi tersebut maka dapat disimpulkan bahwa pemberian ekstrak daun kejibeling dapat meningkatkan aktivitas fagositosis makrofag dan produksi ROI makrofag pada mencit putih strain Swiss yang diinfeksi S.aureus dengan dosis efektif pada $300 \mathrm{mg} / \mathrm{kgBb}$. Perlu dilakukan pemeriksaan lebih lanjut terhadap sitokin TNF- $\alpha$, INF- $\gamma$ serta NO pada mencit swiss yang diinfeksi S.aureus yang diberi ekstrak daun kejibeling untuk melengkapi pembuktian efektivitas dari ekstrak daun kejibeling.

\section{UCAPAN TERIMA KASIH}

Penulis mengucapkan terima kasih kepada Prof. Dr. dr. Winarto, Sp.MK, Sp.M(K), dr. Endang Sri Lestari, PhD. Fakultas Kedokteran, Universitas Diponegoro, yang telah memberikan petunjuk, masukan dan saran selama melakukan penelitian, sehingga beberapa kendala selama penelitian dapat teratasi. Ucapan terima kasih juga penulis haturkan kepada Laboratorium Penelitian dan Pengujian Terpadu (LPPT) UGM yang telah memberikan ijin dan fasilitas selama penelitian. Kepada Laboratorium Mikrobiologi Fakultas kedokteran Universitas Diponegoro yang telah membantu menyediakan S.aureus ATCC 25923. Kepada MIPA Biologi Universitas Diponegoro atas identifikasi tanaman daun kejibeling. Kepada Laboratorium MIPA Kimia Universitas Diponegoro pembuatan ekstrak daun kejibeling serta semua pihak yang tidak 
dapat penulis sebutkan satu persatu hingga selesai penelitian ini.

\section{DAFTAR PUSTAKA}

1. Baratawidjaja KG. Imunologi Dasar. Edisi 8. Jakarta: Balai Penerbit Fakultas kedokteran Universitas Indonesia; 2009

2. Christian, K., William, L. Staphylococcus aureus new evidence for intracellular persistence. Trends in Microbiology. 2008.Volume 17, Issue 2, 59-65.

3. Faroka, D. Rahayu, S.Rifai'i,M. Peran Senyawa Buah Mengkudu (Morinda citrifolia) Terhadap Eekspresi CD62L pada Limpa Mencit yang Diberi Paparan Staphylococcus aureus. El-Hayah Vol. 3, No.2 Maret 2013

4. Klein, E., D. L. Smith, and Laxminarayan. Hospitalizations and deaths caused by methicillinResistant Staphylococcus aureus, United States, 1999-2005. Emerg Infect Dis. 2007 Dec 13(12): 18406.

5. Lee W HAR, Intan ISMAIL. Antioxidant activity, total phenolics and total flavonoid of Syzgium polyanthum (Wight) Walp leaves. Int. J. Med. Arom. Plants, ISSN 2249-4340 Vol.2 No.2 pp. 219-228, June 2012

6. Lusiana, B. Pengaruh Pemberian Ekstrak Umbi Daun Dewa (Gynura pseudochina) Terhadap Aktivitas Fagositosis Makrofag Mencit $\mathrm{C}_{3} \mathrm{H}$ Yang Diinokulasi Sel Adekarsinoma Mamma. Fakultas Kedokteran Universitas Diponegoro. Semarang. 2006
7. Muskhazli M, Dirnahayu M., Nor Azwady A.A., Nurhafiza Y., Nor Dalilah E.and Che $\mathrm{Ku}$ Nurshaira C.K.N. Antibacterial Activity of Methanolic Crude Extracts from Selected Plant Against Bacillus cereus. Pertanika J. Trop. Agric. Sci 2009. 32 (2): 175 - 183

8. Nathan C, Shiloh MU. Reactive Oxygen and Nitrogen Intermediates in the relationship between mammalian host and microbial pathogens. PNAS 2000; 97 (16); p8841-48

9. Nugrahani S, S. Ekstrak Akar, Batang dan Daun Herbba Meniran Dalam Menurunkan Kadar Glukosa Darah. KEMAS 8(1)(2012) 51-59.

10. Nurraihana, H. and NorfarizanHanoon, N. A. Phytochemistry, pharmacology and toxicology properties of Strobilanthes crispus. International Food Research Journal 2013. 20(5): 2045-2056

11. Rr. Sulistiyaningsih. Uji Kepekaan Beberapa Sediaan Antiseptik Terhadap Bakteri Staphylococcus aureus Dan Staphylococcus aureus Resisten Metisilin (MRSA). LPM. Fakultas Farmasi. Universitas Padjajaran.2010

12. Tjahajati, I. Vaksinasi BCG Meningkatkan Aktivitas Fagositosis dan Sekresi Reactive Oxygen Intermediate (ROI) Pada Makrofag Peritoneum Kucing Yang Diinfeksi Dengan Mycobacterium tuberculosis. Jurnal Kedokteran Brawijaya, Vol. XXI, No. 2, Agustus 2005

13. Taylerson. The Health Benefits of Tea Varieties from Camellia sinensis. The Plymouth Student Scientist, 2012, 5, (1), 304-31 